\title{
FORECASTING OPERATIONAL COSTS OF TECHNICAL OBJECTS BASED ON THE EXAMPLE OF RAILBUSES
}

pages: $52-63$

\author{
IZABELA DZIADUCH
}

\begin{abstract}
A B S T R A C T
The purpose of the article is to present the method for forecasting one of the three categories of exploitation costs, i.e., operational costs. The article analyses the available subject literature discussing the methods of measuring operational costs used in the LCC analysis. The presented method for forecasting operational costs of technical objects applies econometric modelling, probability distributions and certain elements of descriptive and mathematical statistics. The statistical data analysis was performed using the functions and commands available in Microsoft Excel. Weibull++ application was also used for constructing probability distributions for random variables and verifying hypotheses. The method was tested on eight single-mode railbuses, operated by one of the regional railway companies providing passenger transport. An ex-post relative forecast error was used to measure the level of accuracy of the operational cost forecast. The analysis of the compliance between forecasted cost value and the actual costs showed extensive convergence as evidenced by the level of estimated relative errors. In forecasting the operational costs of railbuses, the average error was approx. $2.9 \%$. The presented method can, therefore, constitute the basis for the estimation of both operational costs and exploitation costs, which represent an important cost component considered when assessing the profitability of purchasing one of the several competing technical objects offered by the industry.
\end{abstract}

KEY WORDS

forecasting, operational costs, analysis of the life-cycle cost (LCC)

10.2478/emj-2020-0027
Corresponding author:

Izabela Dziaduch

Wrocław University of Economics, Poland ORCID 0000-0001-8067-4707

e-mail: izabela.dziaduch@ue.wroc.pl

\section{INTRODUCTION}

Operational costs of a technical object ${ }^{1}$, i.e., the costs incurred in the course of operation (use) of an object, represent one of the three categories of exploi- tation costs (service life costs). In addition to operational costs, exploitation costs of an object cover (Adamkiewicz, 1983; Dietrich et al., 1999; PN-EN 60300-3-3, 2001):

Dziaduch, I. (2020). Forecasting operational costs of technical objects based on the example of railbuses. Engineering Management in Production and Services, 12(4), 52-63. doi: 10.2478/emj-2020-0027

${ }^{1}$ The term technical object (exploitation object) refers to products serving as a tool for transforming (moving or processing) matter, energy or information. This term is usually used to describe machines, devices and means of transport. 
- damage costs including, e.g., costs of restoring the object's serviceability (in other words repair costs, corrective maintenance costs), penalties resulting from the object's unavailability for operation and the loss of revenues caused by the unplanned interruption of operation;

- preventive maintenance costs, which include the costs of performing preventive maintenance services (inspections and the related repairs) and also, if necessary, the loss of revenues resulting from the planned interruption of operation.

The exploitation costs of a technical object, along with the costs of its acquisition and decommissioning, represent life-cycle costs (Legutko, 2004; PN-EN 60300-3-3, 2001; Woropay, 1996). Experience shows that exploitation costs are 2 to 20 times higher than the acquisition costs of the object (Kowalski et al., 2007; Ryan, 1968). Therefore, the exploitation costs should remain the primary subject of analysis while performing a comparative assessment of the alternative purchase solutions.

The article addresses the role of operational costs in the analysis of life-cycle cost (LCC). It discusses methods for estimating operational costs of technical objects, most commonly used in practice and suggested in the subject literature. Also, it presents a method for forecasting the operational costs of a technical object. Single-mode railbuses operated by one of the regional railway companies providing passenger transport were chosen as the research object. The method was tested to verify its practical applicability when estimating the operational costs of an object.

\section{LITERATURE REVIEW}

The conducted analysis of the available publications, discussing the LCC analysis, shows that:

- the basic components of operational costs cover the costs of energy consumption (e.g., fuel, diesel) and also the labour costs of employees using the object;

- the basic parameters 2 of operational costs include the costs of human labour per unit of time, the number of people using the technical object, the purchase price of an energy unit and energy consumption per time unit;

- the average unit parameter values resulting from the analysis of previous years are adopted in the calculation of operational costs;
- operational costs depend on the value of the technical object readiness index;

- operational costs are calculated on an annual basis and next multiplied by the number of years of the object operation or for the entire life cycle of the technical object;

- the operational costs of a technical object are estimated based on constant prices or a discount coefficient, which considers the fluctuations of money value over time.

Operational costs, in simplified terms, can be calculated as the sum of values of two components, i.e., energy consumption costs (e.g. fuel, diesel) and the costs of human labour:

while:

$$
\overline{k_{u}}=\overline{k_{z e}}+\overline{k_{u}^{p}}
$$

where:

$$
\overline{k_{z e}}=\overline{k_{e n}^{Z}} \cdot \overline{z_{e n}}
$$

$\overline{k_{u}}$ - average cost of a technical object operation per time unit,

$\overline{k_{z e}}$ - average energy cost per time unit,

$\overline{k_{u}^{p}}$ - average labour cost of the personnel using the technical object per time unit,

$\overline{k_{e n}^{Z}}$ - average purchase price of energy unit,

$\overline{z_{e n}}-$ average energy consumption per time unit.

Kumar, Chattopadhyay and Pannu (2004) proposed to consider the readiness of a technical object in addition to specifying the aforementioned two components of the operational cost. The formula for operational cost estimation in the $\mathrm{n}$-th time unit should have the following form:

while:

$$
K_{U}=W_{G} \cdot C_{E} \cdot \overline{k_{u}}
$$

$K_{U}$ - operational costs of a technical object in the nth time unit,

$W_{G}$ - the technical object readiness index,

$C_{E}$ - exploitation period (service life) of a technical object per n-th time unit; exploitation period can be expressed by, e.g., mileage, number of hours of operation, calendar time, clock time, etc.,

$\overline{c_{n z}^{m}}$ - average time between the failure of a technical object caused by corrective or preventive maintenance,

$\overline{c_{n z}^{p}}-$ average downtime of the object operation caused by the need to perform corrective or

${ }^{2}$ The cost parameter is defined by mathematical formulas containing functions and constant values. The parameter cannot represent the sum of other costs (Szkoda, 2007). 
preventive services.

$$
K U=K Z \cdot W_{G}
$$

while:

$$
W_{G}=\frac{\overline{c_{o k}^{d}}}{\overline{c_{o k}^{d}+c_{o k}^{p}}}
$$

where:

$K U$ - operational costs incurred during the life cycle of the technical object,

$K Z$ - purchase price of the object,

$\overline{c_{o k}^{d}}$ - average time of operation till failure,

$\overline{c_{o k}^{p}}$ - average downtime of the object caused by its failure.

It is worth adding at this point that - depending on the type of an object - the cost of energy consumption is measured in different ways. For example, the standards O-CR-001 (Norsok Standard, 1996a) and O-CR-002 (Norsok Standard, 1996b) provide formulas for calculating energy by the devices in which the power demand is constant and independent of production, whereas the studies by Dhillon (1989) and Monteith (1984) present the cost estimation method of fuel consumption for an aircraft and an engine.

In many scientific papers and publications addressing the LCC analysis (e.g., Bernat \& Zieliński, 2006; Bonca \& Sieniuc, 2005a, 2005b; Cieślak, 2008; Koniszewski et al., 2009; Palka-Wyżykowska, 2008; Szul, 2011; Hydraulic Institute or Europump, 2001; Świderski, 2003; Kutut et al., 2008; Man et al., 2011) the exploitation cost is the same as the cost of energy. In the LCC analysis, these costs are perceived as fixed over time. In fact, however, their level depends, e.g., on the method of using technical objects and the habits of their users, as well as energy prices within the calculation period. Energy costs in the LCC analysis are determined at the end of each year's forecast. These costs are either discounted (Bernat \& Zieliński, 2006; Cieślak, 2008; Koniszewski et al., 2009; Szul, 2011; Pasierb et al., 2008; Świderski, 2003; Hydraulic Institute or Europump, 2001) or not (Bonca \& Sieniuc, 2005a, 2005b; Palka-Wyżykowska, 2008; Pasierb et al., 2008) against the base year of the analysis.

\section{METHODOLOGICAL APPROACH}

The conducted investigation, which followed after collecting and organising information on cost estimation of a technical object operation, resulted in a proposal to use the calculation procedure consisting of eight stages for cost forecasting (Fig. 1). The method estimates cost parameters, using the central tendency values and the values of lower and upper quantiles, which allows estimating costs in three variants: the expected (e.g., modal), the optimistic and the pessimistic.

The procedure starts with defining the division structure of an operational cost, i.e. the cost components and the included parameters. The operational cost structure is described by the following correlation:

where:

$$
K U=\left\langle K_{A}, K_{A B}\right\rangle
$$

$K_{A}$ - the set of operational cost components,

$K_{a}-a$-th operational cost component, where $a=$ $1,2, \ldots, A$,

$K_{A B}$ - the set of parameters assigned to the set of operational cost components,

$K_{a b}-b$-th parameter of $a$-th operational cost component, where $b=1,2, \ldots, B$.

The second stage consists of defining the same length (span) of time intervals, $\Delta t^{1}=\Delta t^{2}=\ldots=$ $\Delta t^{D}$, while $d=1,2, \ldots, D$, where $d$ stands for the time interval number, whereas $D$ represents the number of intervals. The range span is the difference between the upper $t_{g}^{d}$ and lower $t_{d}^{d}$ time interval value. The range is bounded top, with the upper limit in the given range being the same as the lower limit of the next range.

The third stage of the method covers calculating the mean value of the $b$-th parameter included in the $a$-th operational cost components for the $d$-th time interval. The estimated mean values of the parameter are assigned at the upper limits of the $d$-th time interval, i.e., $t_{g}^{d}$.

The fourth stage of the method is focused on analysing the correlation occurrence between time $Y$ and the mean values of the $b$-th parameter of the $a$-th operational cost component calculated in the $d$ th time intervals $-X$. For this purpose, the correlation coefficient estimator $\rho$ can be used between the two examined attributes in the population, i.e., the correlation coefficient from the $r$ sample (Greń, 1982):

$$
r=\frac{\sum_{d=1}^{D}\left(x^{d}-\bar{x}\right) \cdot\left(y^{d}-\bar{y}\right)}{\sqrt{\sum_{d=1}^{D}\left(x^{d}-\bar{x}\right) \cdot \sum_{d=1}^{D}\left(y^{d}-\bar{y}\right)}}
$$

where: $x^{d}-X$ variable value, i.e. mean value of the $b$-th parameter of $a$-th operational cost component in the $d$-th time interval, 
Stage 1
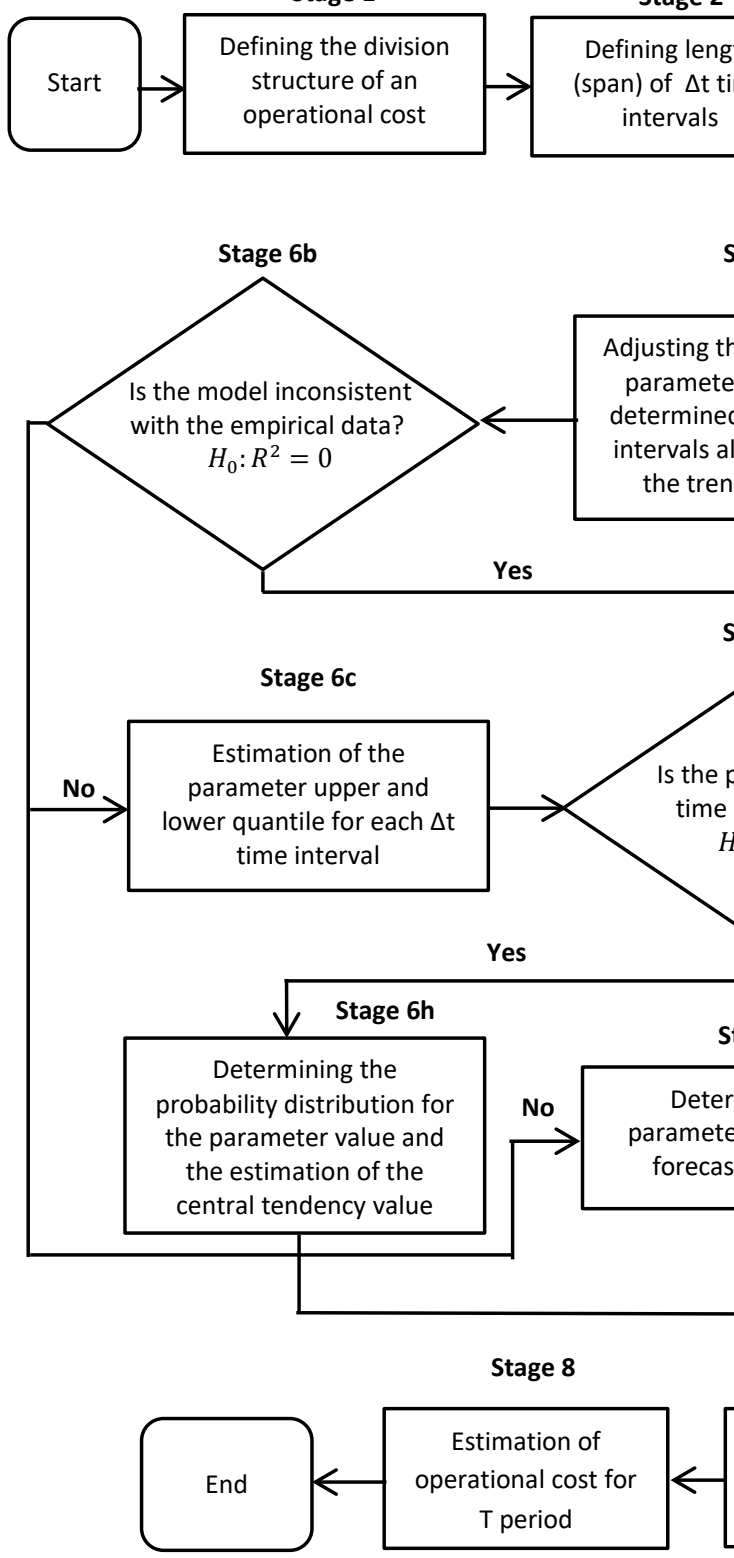

(span) of $\Delta \mathrm{t}$ time intervals
Stage 6a

Adjusting the trend line to the parameter quantile values determined for the $d$-th time intervals along with defining the trend line equation
Stage 3

Calculating the mean value of parameter for $\Delta t$ time interval

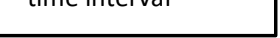


parameters of the $a$-th operational cost components defined for the $d$-th time intervals. For the probability distribution fitting of $X$ variable, any central tendency value should be determined, i.e., the expected value, modal value or median as well as the lower $F\left(x_{q}\right)$ and upper quantile $F\left(x_{1-q}\right) . q$ order quantile for $0<q<1$ takes $x_{q}$ number, which meets the condition:

where:

$$
F\left(x_{q}\right)=\int_{-\infty}^{x_{q}} f(x) d x=q
$$

$F(x)$ - cumulative distribution function of $X$ random variable,

$f(x)$ - probability density function of $X$ variable probability.

If there are grounds to reject $H_{0}$ hypothesis, the trend line (stage 6a) should fit the mean values of the $b$-th parameter defined for the $d$-th intervals. Stage $6 \mathrm{~b}$ consists in examining the model compliance with empirical data using $R^{2}$ coefficient of determination (Dittman, 2003):

where:

$$
R^{2}=\frac{\sum_{t=1}^{Z}\left(\widehat{x_{t}}-\bar{x}\right)^{2}}{\sum_{t=1}^{Z}\left(x_{t}-\bar{x}\right)^{2}}
$$

$x_{t}-$ cost parameter value in $\mathrm{t}$ period,

$\widehat{x_{t}}$ - theoretical cost parameter value in $\mathrm{t}$ period,

$\bar{x}-$ mean value of cost parameter in $\mathrm{z}$ time series.

To verify the coefficient significance, statistics $F$ should be used (Dittman, 2003):

where:

$$
F=\frac{R^{2}}{1-R^{2}} \cdot \frac{D-k-1}{k}
$$

$D-$ number of the dependent variable observations (the same as the number of classes),

$k$ - number of predictor variables in the model excluding the variable with the intercept,

which has Fisher-Snedecor $F$ distribution with $k_{1}=$ $k$ and $k_{2}=D-k-1$ degrees of freedom, whether the model is inconsistent with the empirical data, i.e., $H_{0}: R^{2}=0$ null hypothesis against the alternative $H_{1}: R^{2} \neq 0$ hypothesis. If $F$ value is smaller than $F_{\propto}$ from Fisher-Snedecor $F$ distribution tables for the adopted $\propto$ significance level and also for $k_{1}=k$ and $k_{2}=D-k-1$ degrees of freedom, there are no grounds to reject the $H_{0}$ hypothesis, which means that the coefficient of determination is not significantly different from zero - the model fit to empirical data is far too weak. In this case, such a trend model of the analysed parameter should be found, for which $F$ statistics can show a correlation occurrence between the data (stage 6a). However, if the coefficient of determination is statistically different from zero, the lower $F\left(x_{q}\right)$ and upper quantile values $F\left(x_{1-q}\right)$ of the $b$-th parameter of the $a$-th operational cost component for each $\Delta t$ time interval should be determined (stage $6 \mathrm{c}$ ). Next, in the course of stage $6 \mathrm{~d}$, the correlation occurrence between $Y$ time and the defined lower $F\left(x_{q}\right)$ and upper quantile values $F\left(x_{1-q}\right)$ should be analysed using a correlation coefficient estimator. The hypothesis can be verified using Student's $t$ distribution with $D-2$ degrees of freedom. If there are no grounds to reject the $H_{0}$ hypothesis, the theoretical distribution function has to fit the quantile values of the $b$-th parameter of the $a$-th operational cost component (stage $6 \mathrm{~h}$ ). For the fitted probability distribution of $X_{q}$ variable, any central tendency value should be defined. However, if there are grounds to reject the $H_{0}$ hypothesis, the theoretical distribution functions have to fit the quantile values of the $b$-th parameter of the $a$-th operational cost component (stage 6e) and the analysis (stage 6f) - using $R^{2}$ coefficient of determination - of the developed model compliance with empirical data has to be conducted. The assessment of correlations is performed by testing $H_{0}: R^{2}=0$ and $H_{1}: R^{2} \neq 0$ hypotheses. The hypothesis can be verified using statistics which has Fisher-Snedecor $F$ distribution with $k_{1}=k$ and $k_{2}=D-k-1$ degrees of freedom. If there are grounds to adopt $H_{0}: R^{2}=0$ null hypothesis, then such a trend model of the analysed parameter should be defined, for which $F$ statistics will determine the correlation occurrence between the data (stage 6e). In the case when $R^{2}$ coefficient of determination is statistically different from zero both in stage $6 \mathrm{~b}$ and $6 \mathrm{f}$, then in the course of stage $6 \mathrm{~g}$, the future value of the $b$-th parameter of the $a$-th cost component is determined. This value is obtained by extrapolating the trend function, i.e., by substituting time variable in the model with $t$ moment number or $T$ period for which the forecast is prepared.

The seventh stage consists of the estimation of cost components. The estimation of cost components is based on analytical expressions defined in the second part of the article or by the researcher. The cost component value estimated for the entire life cycle of the $T$ technical object, for which at least one of the parameters remains time-dependent is equal to: 


$$
K_{a}=\sum_{t=1}^{T} K_{a_{t}}
$$

Whereas the cost component value for the $T$ entire life cycle of the technical object, for which none of the parameters depends on time should be determined based on the following correlation:

$$
K_{a}=K_{a_{t=1}} \cdot T
$$

Stage eight is focused on summing up the cost components included in the operational cost:

$$
K U=\sum_{a=1}^{A} K_{a}
$$

\section{CONDUCTING THE RESEARCH AND RESULTS}

\subsection{OBJECT AND PERIOD}

The method for forecasting the costs of a technical object operation was made for eight single-mode railbuses of type $\mathrm{X}$ (manufactured by the same producer), which are a homogeneous set of objects in terms of construction solutions. The railbuses are owned by the Lower Silesia Marshal's Office and operated by a regional rail carrier. Because of a signed statement regarding data confidentiality, the name of the rail carrier could not be disclosed, and the marks (inventory numbers) of vehicles had to be changed.

Some analysed railbuses were taken by the analysed company from another railway company, and others were new, bought by the Regional Government and rented to the analysed company. The vehicles were in possession of the analysed company at different times of their life, as illustrated in Fig. 2.

The period of research analysis encompassed 42 months of rail carrier performance, from December 2013 to June 2017.

The analysis period addressed the events and activities recorded from the 1st till the 50th month of the railbus exploitation. The exploitation time covered by the study was not identical for all analysed railbuses, i.e., for buses 1,2 and 3 determining the operational cost parameters was possible from the 9th till the 50th month of exploitation. However, for the buses No. 4 and 5, it was possible from the 1st till the 19th month of exploitation, whereas for other objects from the 1st till the 16th, 13th and 12th month, i.e., for buses 6,7 and 8 , respectively.

\subsection{Assumptions}

The cost components were estimated, adopting the following assumptions:

- A railbus crew consists of one conductor and one driver;

- The central tendency measure is the expected value of $\mathrm{E}(\mathrm{X})$ parameters;

- The adopted horizon of cost forecasting is 50 months;

- The exploitation month is not the same as the calendar month;

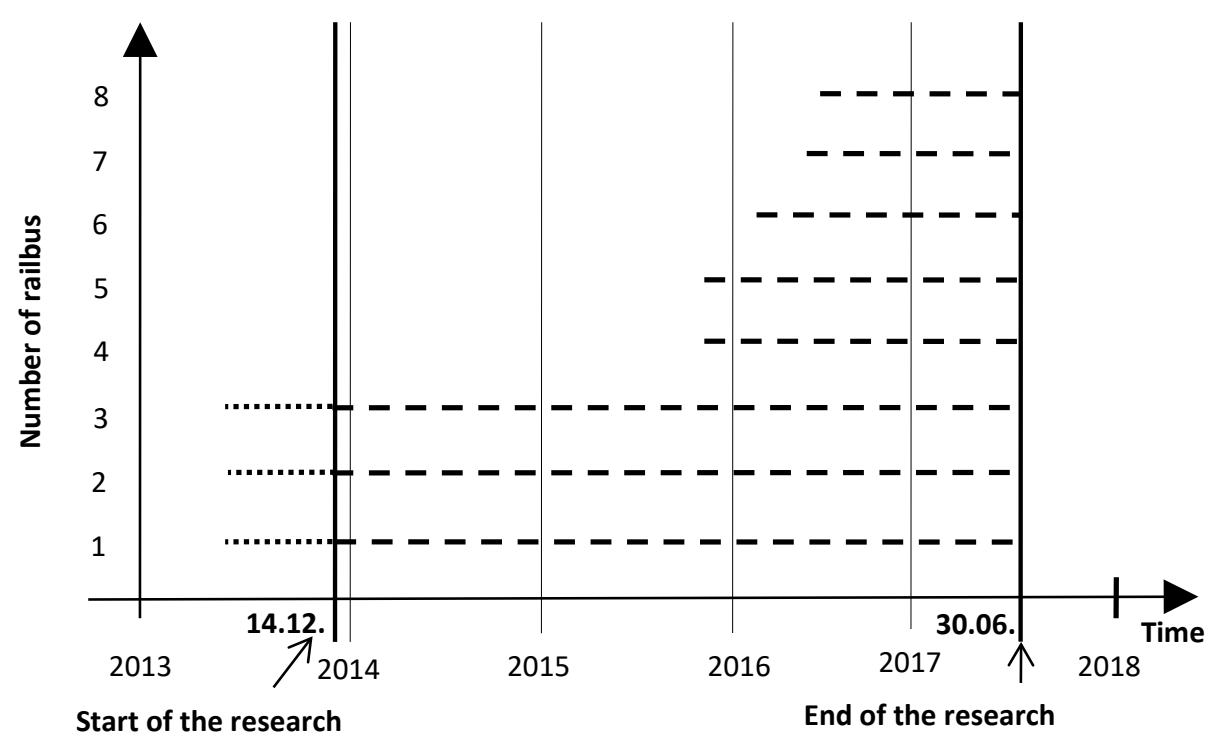

Railbus operated by another rail carrier

_ _ $\ldots$ Railbus operated by analysed rail carrier

Fig. 2. Schedule of the performed research analysis 


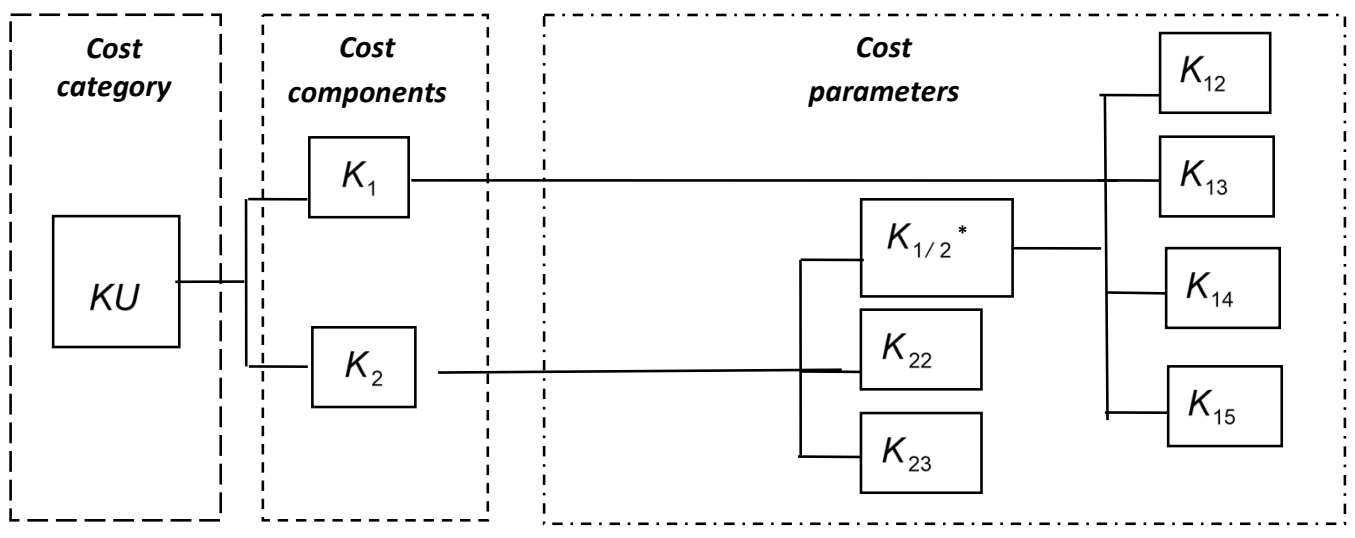

Fig. 3. Structure of costs distribution of a railbus operation adopted for calculations

- When calculating the number of days in the month of exploitation, the calendar year was considered to have 365 days;

- Costs are not discounted;

- The structure of operating costs consists of two components and seven cost parameters included in them (Fig. 3)

- Cost components were defined based on the following formulas:

$$
\begin{gathered}
K_{1}=K_{1 / 2} \cdot\left[\left(K_{12} \cdot K_{13}\right)+\left(K_{14} \cdot K_{15}\right)\right] \\
K_{2}=K_{1 / 2} \cdot K_{22} \cdot K_{23}
\end{gathered}
$$

- The accuracy degree of the operational cost forecast was measured using the ex-post relative forecast error from the formula (Cieślak, 2005):

$$
\gamma_{t}=\frac{K U_{t}-K U_{t}^{r z}}{K U_{t}} \cdot 100
$$

where:

$\gamma_{t}$ - ex-post relative forecast error at the end of the $\Delta t$ time interval,

$K U_{t}$ - forecasted operational cost value at the end of the $\Delta t$ time interval,

$K U_{t}^{r Z}-$ actual value of the vehicle operational costs in the $\Delta t$ time interval.

\subsection{APPLICATION OF THE METHOD FOR FORE- CASTING THE OPERATIONAL COSTS OF TECH- NICAL OBJECTS}

The statistical data analysis was performed using the functions and commands available in Microsoft Excel. Weibull++ application was also used, which allowed, e.g.:

- developing histograms and cumulative distribution functions for random variables,

- the verification of hypotheses (carried out using Spearman's rho $\varphi$ correlation coefficient) in the form of distributions of the analysed random variables,

- the estimation of the unknown distribution characteristics.

For the purposes of the developed method, time series for the operational cost parameters were constructed by averaging the cost parameter per month of railbus exploitation (Fig. 4). In turn, Fig. 5 shows the course of the cumulative distribution function in the probability distribution grid for the operational cost parameters of railbuses.

The list of parameters necessary to estimate the cost components described by formulas (16) and (17) is presented in Table 1. The analysis of the collected information shows that the operational cost parameters are not time-dependent. The analysis indicates that the distributions of daily mileage of railbuses, a train driver's cost of work per 1 kilometre of the route, diesel consumption per kilometre of the route and the purchase price of a litre of diesel can be modelled with a normal distribution - a high value of Spearman's rho $\varphi$ correlation coefficient was received, ranging from 0.88 to 0.99 . In turn, the cost of a conductor's work per kilometre of the route can be described by a log-normal distribution $(\varphi=0.99)$. The expected value as well as $F\left(x_{q}\right)$ lower and $F\left(x_{1-q}\right)$ upper quantile for $q=0.05$ were determined for the adjusted probability distributions.

The relative errors made when measuring operational costs at the end of the $\Delta t$ time interval, i.e., the last period, in which the actual costs were recorded, are summarised in Table 2. The prognostic value of the described method is high, as confirmed by the calculated mean value of the relative error module. In forecasting the operational costs of railbuses, the average error was approx. $2.9 \%$. 

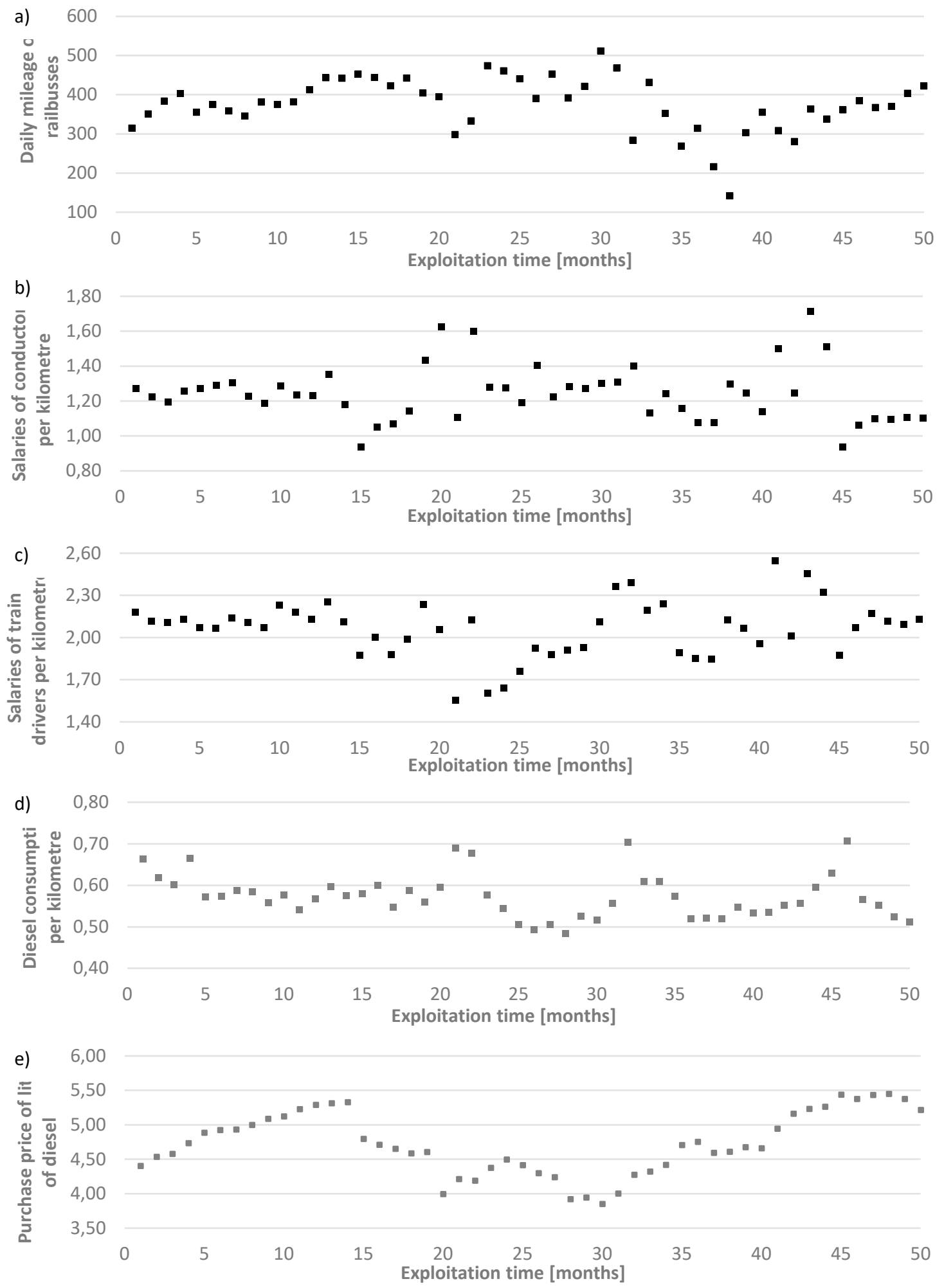

Fig. 4. Data for the time series analysis covering a given operational cost parameter of railbuses: a) daily mileage of railbuses, b) salaries of conductors per kilometre of the route, c) salaries of train drivers per kilometre of the route, d) diesel consumption per kilometre of the route, and e) purchase price of a litre of diesel 

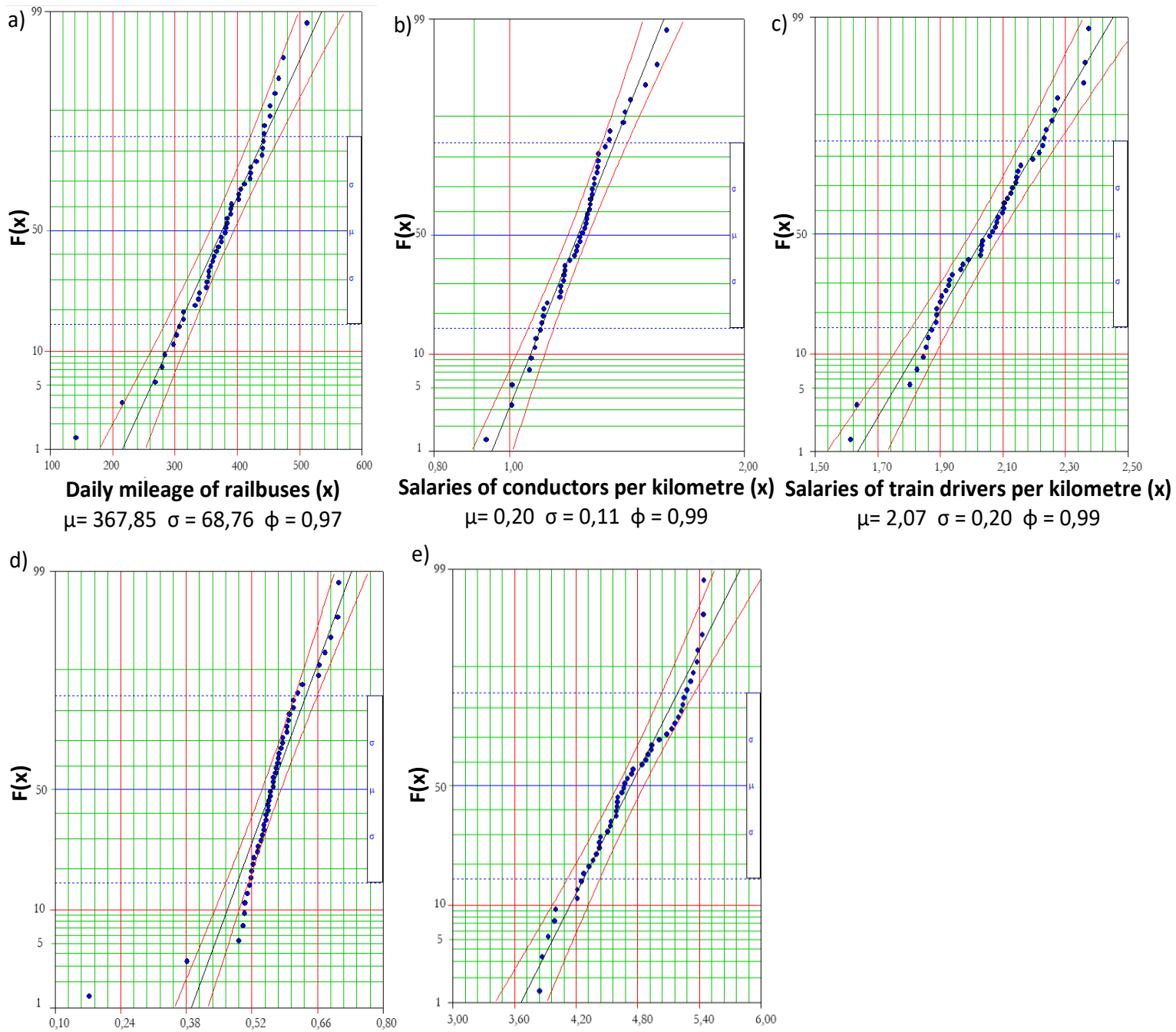

Diesel consumption per kilometre $(\mathbf{x})$ $\mu=0,58 \sigma=0,07 \quad \phi=0,99$

Purchase price of a litre of diesel (x) $\mu=4,75 \sigma=0,51 \quad \phi=0,88$

Fig. 5. Distribution of operational cost parameters for test objects: a) daily mileage of railbuses, b) salaries of conductors per kilometre of the route, c) salaries of train drivers per kilometre of the route, d) diesel consumption per kilometre of the route, and e) purchase price of a litre of diesel

The list of parameters necessary to estimate the cost components described by formulas (16) and (17) is presented in Table 1. The analysis of the collected information shows that the operational cost parameters are not time-dependent. The analysis indicates that the distributions of daily mileage of railbuses, a train driver's cost of work per 1 kilometre of the route, diesel consumption per kilometre of the route and the purchase price of a litre of diesel can be modelled with a normal distribution - a high value of Spearman's rho $\varphi$ correlation coefficient was received, ranging from 0.88 to 0.99 . In turn, the cost of a conductor's work per kilometre of the route can be described by a log-normal distribution $(\varphi=0.99)$. The expected value as well as $\mathrm{F}\left(\mathrm{x}_{\mathrm{q}}\right)$ lower and $\mathrm{F}\left(\mathrm{x}_{1-\mathrm{q}}\right)$ upper quantile for $\mathrm{q}=0.05$ were determined for the adjusted probability distributions.

The relative errors made when measuring operational costs at the end of the $\Delta t$ time interval, i.e., the last period, in which the actual costs were recorded, are summarised in Table 2. The prognostic value of the described method is high, as confirmed by the calculated mean value of the relative error module. In forecasting the operational costs of railbuses, the average error was approx. $2.9 \%$. 
Tab. 1. Parameters of the operational cost components for time intervals presented as the months of vehicle exploitation

\begin{tabular}{|c|c|c|c|c|c|c|}
\hline & & \multicolumn{5}{|c|}{ PARAMETERS OF THE OPERATIONAL COST COMPONENTS } \\
\hline & & $K_{1 / 2}$ & $K_{12}$ & $K_{14}$ & $K_{22}$ & $K_{23}$ \\
\hline \multirow{5}{*}{ StAge 4} & Correlation coefficient $(r)$ & -0.22 & -0.07 & 0.06 & 0.18 & -0.25 \\
\hline & & $t=-1.59$ & $t=-0.51$ & $t=0.45$ & $t=1.27$ & $t=-1.78$ \\
\hline & For $\propto=0,05$ & $p=0.12$ & $p=0.61$ & $p=0.65$ & $p=0.21$ & $p=0.08$ \\
\hline & & $p>\propto$ & $p>\propto$ & $p>\propto$ & $p>\propto$ & $p>\propto$ \\
\hline & Accepted hypothesis & $H_{0}: \rho=0$ & $H_{0}: \rho=0$ & $H_{0}: \rho=0$ & $H_{0}: \rho=0$ & $H_{0}: \rho=0$ \\
\hline \multirow{5}{*}{ StAGE 5} & $\begin{array}{c}\text { Type of probability } \\
\text { distribution }\end{array}$ & Normal & Log-normal & Normal & Normal & Normal \\
\hline & Distribution matching $(\varphi)$ & 0.97 & 0.99 & 0.99 & 0.99 & 0.88 \\
\hline & $E(X)$ & 367.85 & 1.23 & 2.07 & 4.75 & 0.58 \\
\hline & $F\left(x_{0,95}\right)$ & 480.95 & 1.46 & 2.41 & 5.60 & 0.69 \\
\hline & $F\left(x_{0,05}\right)$ & 254.76 & 0.02 & 1.72 & 3.91 & 0.47 \\
\hline
\end{tabular}

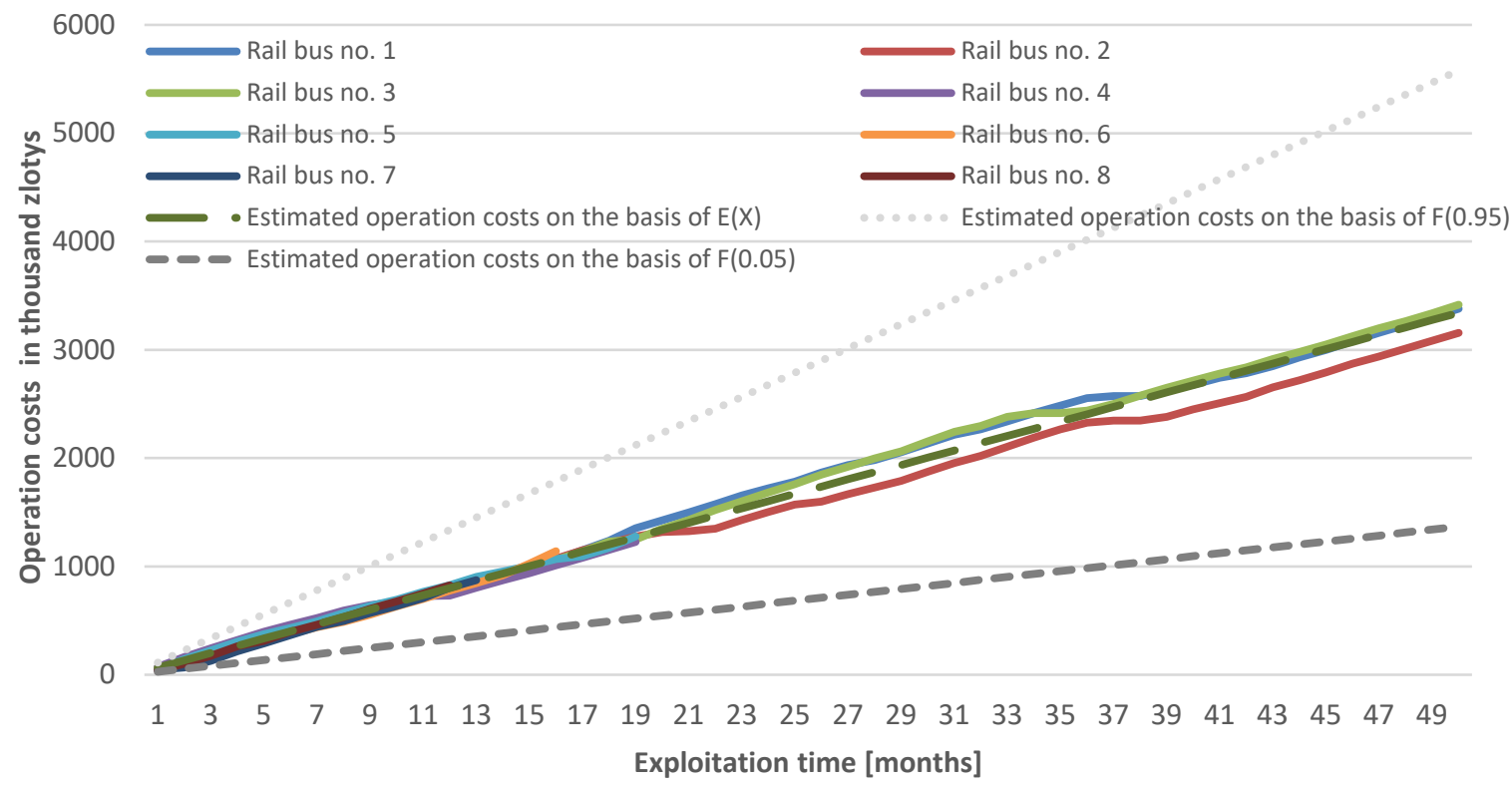

Fig. 6. Cumulative operational costs of railbuses in the analysed period presented as the months of exploitation

Tab. 2. Relative errors in measuring operational costs of railbuses

\begin{tabular}{|c|c|c|c|c|c|}
\hline RAILBUS NUMBER & $\begin{array}{l}\text { LAST MONTH OF THE RAILBUS } \\
\text { EXPLOITATION T }\end{array}$ & $K U_{t}^{r z}$ & $K U_{t}$ & $\gamma_{t}$ & MEAN ReLATIVE ERROR \\
\hline 1 & 50 & 3379357 & 3340998 & $-1.1 \%$ & \multirow{8}{*}{$2.9 \%$} \\
\hline 2 & 50 & 3156515 & 3340998 & $5.5 \%$ & \\
\hline 3 & 50 & 3416362 & 3340998 & $-2.3 \%$ & \\
\hline 4 & 19 & 1226472 & 1269579 & $3.4 \%$ & \\
\hline 5 & 19 & 1276996 & 1269579 & $-0.58 \%$ & \\
\hline 6 & 16 & 1140901 & 1069119 & $-6.7 \%$ & \\
\hline 7 & 13 & 873708 & 868659 & $-0.58 \%$ & \\
\hline 8 & 12 & 825694 & 801839 & $-3.0 \%$ & \\
\hline
\end{tabular}




\section{CONCLUSIONS}

The article discusses the method aimed at forecasting operational costs of technical objects. The presented method allows estimating operational costs in the adopted life-cycle of a technical object. The estimation of costs within three variants, i.e., the expected variant (e.g., modal), the optimistic variant and the pessimistic variant, allows determining the cost range of a technical object operation. It is a universal method, as it can be used for any technical object (provided that the historical data related to the operation of identical objects or homogeneous objects, in terms of their structural solutions, were collected). In addition, this method allows capturing the variability of maintenance costs over time, arising from the gradual changes in object parameters, resulting from technical wear, by examining the correlations of technical parameters such as, e.g., diesel consumption. It should be noted that in the presented method, the level of costs depends on, e.g.:

- the number of components adopted for analysis and the cost parameters identified within them;

- the adopted exploitation time unit;

- the adopted central tendency measure and the confidence interval in the calculations of quantile values.

The analysis of the compliance between forecasted operational costs and the actual costs showed a high correlation, as evidenced by the level of estimated relative errors. Therefore, the method, which was approached as the possibility of its application to estimate operational costs during future periods, has a relatively high prognostic value.

The presented method can also become the basis for estimating total operational costs, which remain an important cost component, considered when assessing the profitability of purchasing one of several competing technical objects offered by the industry. Thus, the modification of the presented method and its implementation constitute the next stage of the author's research covering the LCC analysis.

\section{ACKNOWLEDGEMENT}

\section{Ministerstwo Nauki \\ i Szkolnictwa Wyższego}

This project is financed by the Ministry of Science and Higher Education in Poland under the programme "Regional Initiative of Excellence" 2019-2022 project num- ber 015/RID/2018/19 total funding amount 10721 040,00 PLN

\section{LITERATURE}

Adamkiewcz, W. (1983). Badania i ocena niezawodności maszyny $w$ systemie transportowym [Research and evaluation of machine reliability in the transport system]. Warszawa, Poland: Wydawnictwa Komunikacji i Łączności.

Bernat, M., \& Zieliński, T. (2006). Porównanie kosztów cyklu życia standardowych i energooszczednych silników indukcyjnych niskiego napięcia [Life Cycle Costs comparison of standard and low voltage induction motor]. Napędy i Sterowanie, 2, 80-85.

Bonca, Z., \& Sieniuc, J. (2005a). Ocena techniczno-ekonomiczna stosowania pomp ciepła w systemach ogrzewania wolnostojących budynków mieszkalnych. Część 1 [Technical and economical assessment of application of heat pumps for heating of detached residential buildings. Part 1]. Technika Chłodnicza i Klimatyzacyjna, 9, 336-344.

Bonca, Z., \& Sieniuc, J. (2005b). Ocena techniczno-ekonomiczna stosowania pomp ciepła w systemach ogrzewania wolnostojących budynków mieszkalnych. Czesśc 2 [Technical and economical assessment of application of heat pumps for heating of detached residential buildings. Part 2]. Technika Chłodnicza i Klimatyzacyjna, 10, 374-378.

Cieślak, M. (Ed.). (2005). Prognozowanie gospodarcze. Metody i zastosowania [Economic forecasting. Methods and applications]. Warszawa, Poland: Wydawnictwo Naukowe PWN.

Cieślak, M. (2008). Life cycle costs of pumping stations. World Pumps, 505, 30-33.

Dhillon, B. S. (1989). Life Cycle Costing: Techniques, Models and Applications. New York, USA: Gordon and Breach.

Dhillon, B. S. (1996). Optimum life cycle and labour costs estimation of repairable equipment. Microelectronics Reliability, 36(2), 227-229.

Dietrich, M., Kocańda, S., Krytkowski, B., Ozimowski, W., Stupnicki, J., \& Szopa, T. (1999). Podstawy konstrukcji maszyn. Tom 1 [Basics of machine design. Volume 1]. Warszawa, Poland: Wydawnictwa Naukowo-Techniczne.

Dittman, P. (2003). Prognozowanie w przedsiębiorstwie [Forecasting in company]. Kraków, Poland: Oficyna Ekonomiczna.

Greń, J. (1982). Statystyka Matematyczna. Modele i zadania [Mathematical statistics. Models and tasks]. Warszawa, Poland: Państwowe Wydawnictwo Naukowe.

Hydraulic Institute or Europump (2001). Pump Life Cycle Costs: A Guide to LCC Analysis for Pumping Systems. Retrieved from https://www.energy.gov/sites/prod/ files/2014/05/f16/pumplcc_1001.pdf

Koniszewski, A., Jasiukiewicz, P., \& Bonca, Z. (2009). Aspekt ekonomiczny ogrzewania wolnostojącego budynku mieszkalnego powietrzną pompą ciepła [Economic aspect of individual house heating with 
an air heat pump]. Technika Chłodnicza i Klimatyzacyjna, 11-12, 406-413.

Kowalski, Z., Kulczycka, J., \& Góralczyk, M. (2007). Ekologiczna ocena cyklu życia procesów wytwórczych (LCA) [Ecological life cycle analysis of the production processes]. Warszawa, Poland: Wydawnictwo Naukowe PWN.

Kumar, D., Chattopadhyay, G., \& Pannu, H.S. (2004). Total Cost of Ownership for Railway Assets: A Case Study on Boxn Wagons of Indian Railways. In Proceedings of the Fifth Asia-Pacific Industrial Engineering and Management Systems Conference 2004, 12-15 December 2004, Gold Coast, Australia.

Kutut, I., Ginevičius, R., \& Kutut, V. (2008). Diversification of activity in the context of companies life cycle. Business: Theory and Practice, 9(3), 169-179. doi: 10.3846/1648-0627.2008.9.169-179

Legutko, S. (2004). Podstawy eksploatacji maszyn i urządzeń [Basic of machinery and equipment exploitation]. Warszawa, Poland: Wydawnictwa Szkolne i Pedagogiczne.

Man, M., Dima, I. C., \& Pachura, P. (2011). The cost for the entire life cycle of the product respecting quality standards. Polish Journal of Management Studies, $4(2), 15-22$

Monteith, D. O. (1984). Reliability considerations for power system design. Telecommunications Energy Conference, INTELEC '84 International, 491-494.

Norsok Standard (1996a). O-CR-001: Life cycle cost for systems and equipment. Rev. 1. Retrieved from https:// www.standard.no/pagefiles/1138/o-cr-001r1.pdf

Norsok Standard (1996b). O-CR-002: Life cycle cost for production facility. Rev. 1.

Palka-Wyżykowska, K. (2008). Metoda LCC i jej przydatność do ekonomicznej oceny systemów energetycznych na przykładzie systemów grzewczych w budownictwie mieszkaniowym [The LCC method and its suitability for the economic assessment of energy systems, for example heating systems in residential buildings]. Retrieved from http://www.mech.pg.gda.pl/ktc/wtargans/osiagi/Palka_chlodnictwo.pdf

Pasierb, S., Bogacki, M., Osicki, A., \& Wojtulewicz, J. (2008). Odnawialne źródła energii. Efektywne wykorzystanie $w$ budynkach. Finansowanie przedsięwzięć [Renewable energy sources. Efficient use in buildings. Financing projects]. Retrieved from http://www.czestochowa.energiaisrodowisko.pl/poradniki/poradnikoze/PORADNIK_ OZE_v2.pdf

PN-EN 60300-3-3 (2001). Zarządzanie niezawodnością. Przewodnik zastosowań. Szacowanie kosztu cyklu życia [Reliability management. Application Guide Estimating the Life Cycle Cost].

Ryan, W. (1968). Procurement Views of Life Cycle Costing. Proceedings of the 1968 Annual Symposium on Reliability, Boston, MA, 16-18 January, 164-168.

Szkoda, M. (2007). Koszt cyklu trwałości jako kryterium efektywności modernizacji lokomotyw spalinowych [Life cycle cost as a criterion of effectiveness of diesel locomotives modernization]. Problemy Eksploatacji, 2, 159-169.
Szul, T. (2011). Ocena efektywności energetycznej i ekonomicznej przy doborze źródła ciepła dla budynku mieszkalnego [Evaluation of energy and economic efficiency in the choise of the boiler to heat a residential building]. Technika Rolnicza Ogrodnicza Leśna, 4, 16-18.

Świderski, M. (2003). Analiza LCC narzędziem wspomagajacym ocene projektów inwestycyjnych związanych $z$ technikg pompowa [Life Cycle Cost Analysis - a tool for supporting the assessment of investment projects related to the pumping technology]. IX Forum Użytkowników Pomp. Szczyrk, 1-3 października.

Woropay, M. (1996). Podstawy racjonalnej eksploatacji maszyn [The basics of the rational exploitation of the machines]. Bydgoszcz - Radom, Poland: Wydawnictwo Instytutu Technologii Eksploatacji. 